\title{
The Star Charts of Ignatius Kögler (1680-1746) in the Korean Court
}

\author{
Richard A. Pegg \\ Asian Art Curator, Maclean Collection, Chicago \\ richardapegg@aol.com
}

\begin{abstract}
Star-chart screens based on the work of the Jesuit Ignatius Kögler (1680-1742), functioned in the eighteenth-century Korean court as a way of consolidating imperial authority around the calendar and more broadly conceptions of space and time. This occurred in the aftermath of the collapse of Ming calendrical authority and in the context of the developing relationship between Korea and the Qing court. The network of envoys that brought back astronomical science between the Joseon court in Korea and the Ming and Qing courts in China is discussed, and Kögler's star chart of 1723 is compared with several large format Korean star chart screens that acted as symbols of royal power and legitimacy in the Joseon dynasty (1392-1910) court.
\end{abstract}

\section{Keywords}

Ignatius (Ignaz) Kögler - Jesuit star charts - Joseon Korea - Qing China - King Sukchong - King Yeongjo

\section{Jesuit Celestial Cartography}

Jesuit astronomy and celestial maps, which first appeared in China during the late Ming dynasty (1368-1644), were introduced to Korea during the early Qing dynasty (1644-1912). The Chinese court from the late Ming recognized the importance of correcting calendrical errors to the maintenance of the concept of "order" (zhi 秩) of "time and space" as confirmed by the Mandate of Heaven, and the making of accurate calendars and star charts symbolized that

(C) RICHARD A. PEGG, 2019 | DOI:10.1163/22141332-00601004

This is an open access article distributed under the terms of the prevailing CC-BY-NC license at the time of publication. 
imperial authority. ${ }^{1}$ Although Jesuit contributions to this process were fraught with controversy during the turbulent years of the seventeenth century, by the eighteenth century, they had achieved a much more stable position at court. The Jesuit Ignatius Kögler (1680-1746) made substantial contributions to both calendar reform and the making of star charts for the Qing, efforts that Korean envoys brought back to their own court. ${ }^{2}$ Although the Jesuits themselves were forbidden in Korea, a number of large-format single-screen star charts, based on Kögler's work, were made in the Korean court during the 1740 s and 1750s. Scholarship about the role of the screens in Korea has been limited, even though they had a substantially different role at the Joeson court than at the Qing court. ${ }^{3}$ Moreover, these screens provide important evidence for the transmission of Jesuit science from China as part of developing Korean science in the eighteenth century. ${ }^{4}$ The network of envoys that brought back

1 F. Richard Stephenson. "Chinese and Korean Star Maps and Catalogues," in The History of Cartography, ed. J. B. Harley and David Woodward (Chicago: University of Chicago Press, 1994), 2/2, 511-78, here 569 . Robert Batchelor points to the recent reconceptualization of time and space during the late Ming and early Qing from various historians. See Robert Batchelor, "Maps, Calendars, and Diagrams: Space and Time in Seventeenth-Century Maritime East Asia," in Tonio Andrade and Xing Hang, eds., Sea Rovers, Silver and Samurai: Maritime East Asia in Global History (University of Hawaii Press, 2016), 86-113 and for a traditional understanding of Chinese time and space, see Chun-Chieh Huang and Erik Zurcher, Time and Space in Chinese Culture (Brill: Leiden, 1995).

2 See Christian Stucken, Der Mandarin des Himmels: Zeit und Leben des Chinamissionars Ignaz Kögler SJ (1680-1746) (Sankt Augustin: Institut Monumenta Serica, 2003), esp. the bibliography 385-440. See Catherine Jami, "Mathematical Knowledge in the Chongzhen lishu," in Western Learning and Christianity in China: The Contribution and Impact of Johann Adam Schall von Bell sJ (1592-1666), Monumenta Serica Monograph Series 35/2 (Nettetal: Steyler Verlag, 1998), 661-74; Benjamin Elman, On Their Own Terms: Science in China, 1550-19oo (Cambridge, MA: Harvard University Press, 2005); Sun Xiaochun, "Chongzheng lishu: xingbiao he xingtu," Ziran kexueshi yanjiu 4 (Oct. 1995): 323-30; and Chu Longfei and Shi Yunli, Chongzheng lishu (Hefei: Zhongguo kexue jixi chubanshe, 2017).

3 See Yongbom Lee, "On a New Star Map Preserved in the B bju-sa Temple," Yoksa Hokkan $3^{1}$ (1966): 1-66; Joseph Needham and Lu Gwei-Dien, "A Korean Astronomical Screen of the MidEighteenth Century from the Royal Palace of the Yi Dynasty (Choson Kingdom, 1392 to 1910)," Physis 8, no. 2 (1966): 137-62, here 137; Joseph Needham, Gwei-Djen Lu, John H. Combridge, and John S. Major, The Hall of Heavenly Records: Korean Astronomical Instruments and Clocks 1380-1780 (Cambridge University Press, 1986); and Il-seong Nha and Yong-sam Lee, "The Eight-Fold Screen Star Map," Technical Report of National Folk Museum (1995).

4 See Stephenson, "Chinese and Korean Star Maps and Catalogues"; Lim Jongtae, "Matteo Ricci's World Maps in Late Joseon Dynasty," The Korean Journal for the History of Science 33, no. 2 (2011): 277-96, and Jongtae, "Learning Western Astronomy from China: Another Look at the 
astronomical science to the Joseon court in Korea from the Ming and Qing courts in China illustrates the nature of this scientific transmission, while comparison of Kögler's star chart of 1723 with several large format Korean star chart screens, clarifies the role of these screens as symbols of royal power and legitimacy in the Joseon dynasty (1392-1910) court.

In 1720, Ignatius Kögler (1680-1746) became the sixth Jesuit to be appointed Jianzheng (監正 Director) of the Qintianjian (欽天監 Directorate of Astronomy) in Beijing, a position he held until his death. ${ }^{5}$ Kögler's publications in relation to this role began in 1723 with his Huangdao zong xingtu ("Two general maps of the stars relative to the ecliptic," 黃道總星圖) and ended with his final treatise of 1742 , the imperially commissioned book entitled Lixiang kaocheng houbian (Later volumes of the summation of measurements and observations, 歷象考成后編). The latter updated another 1723 publication by Kögler, Lixiang kaocheng (Summation of measurements and observations, 曆 象考成). The Lixiang was an in depth treatise on astronomy and calendrical science with sections on theoretical astronomy, practical technique and astronomical tables. In addition, Kögler also prepared, with the German Jesuit Ferdinand Augustin Haller von Hallerstein (1703-74), the Yixiang kaocheng (Official description of the imperial astronomical instruments in Beijing, 儀象考成) in $1744 \cdot{ }^{6}$ Astronomical instrumentation was the means by which an accurate accounting of the "order" of space and time could be confirmed, bolstering imperial authority.

Kögler's 1723 Huangdao zong xingtu (Figure 3.1) was a high quality production printed in Beijing with the Latin title Tabula stellarum universalis eclipticae. ${ }^{7}$ The star chart, spread over two pages, presents a complex understanding of the heavens. Across the top, a ribbon indicated the title (center),

Introduction of the Shixian li Calendrical System into Late Joseon Korea," The Korean Journal for the History of Science 34, no. 2 (2012): 197-217.

5 Kögler was buried in Beijing in the Zhalan cemetery where a dedicatory stele still stands. The site is now located on the campus of Beijing Administrative College with sixty-three of the original stele.

6 After Kögler died, von Hallerstein became the seventh jianzheng of the Qintianjian for the next thirty years. Anton Gogeisl (1701-71) succeeded Antonio Pereira (1690-1743) as assistant jianzheng for the next twenty-seven years.

7 A rare original copy in excellent condition, formerly part of the Philip Robinson Collection and shown to Joseph Needham in 1953, recently came up for sale and is now in a private collection. This copy can be found in Sino-European Imprints of the $17^{\text {th }}$ and $18^{\text {th }}$ Century, Maggs catalogue 1480, entry 27, 2016 (available online). According to the notes, this copy has annotations likely by Antoine Gaubil (1689-1759). Part of Gaubil's archive was a letter from Kogler dated March 13, 1726 that mentions this copy of the star chart. 


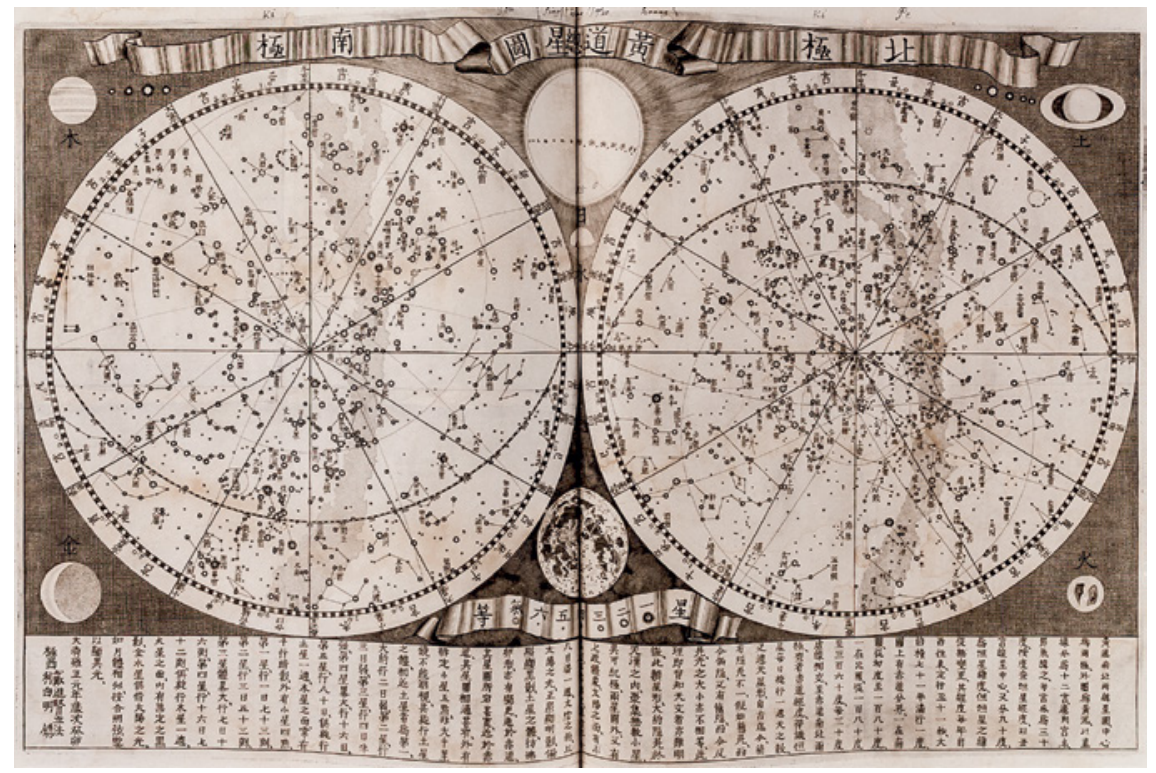

FIGURE 3.1 Ignatius Kögler (1680-1746, Dai Jinxian 戴進賢), Huangdao zong xingtu (Two general maps of the stars relative to the ecliptic, 黃道總星圖), China, Qing dynasty, dated 1723, Beijing, sheet map, ink on paper

the southern pole (left), and the northern pole (right). The two globular hemispheres take up most of the pages. The "seven directors" (qizheng 七政) are the large sun above, with an arc of sunspots across the face, and the moon below, along with the five known planets, Mercury, Venus, Mars, Saturn, and Jupiter. ${ }^{8}$ A short ribbon at the bottom presents the key of the six Ptolemaic stellar magnitudes ( $x$ ingdeng 星等) in addition to nebulae ( $q i$ 氣, lit. "gas" or "breath"). ${ }^{9}$ A star's relative size on the maps indicates its apparent brightness. The long lower inscription discusses the principles and observations of Galileo Galilei (1570-1612), Giovanni Domenico Cassini (1625-1712) and Christian Huygens (1629-95) as well as how to measure latitude and longitude of fixed stars, novae and supernovae, the seven directors, sunspots, and planetary moons. ${ }^{10}$ This passage is dated the first year of the Yongzheng reign of the Great Qing

The planets are presented and labeled using their traditional associated five elements (wuxing) of fire (Mars), water (Mercury), earth (Saturn), metal (Venus) and wood (Jupiter) respectively.

9 Stephenson, "Chinese and Korean Star Maps," 569.

10 Needham, Hall of Heavenly Records, full translation 161-64. 
dynasty (guimao, 1723), signed by the "far Westerner" Dai Jinxian (Kögler) and engraved by Li Baiming (Ferdinando Bonaventura Moggi, 1684-1761). ${ }^{11}$

Kögler's star charts are in polar stereographic projection from the north/ south ecliptic pole to the ecliptic or huangdao (黃道, lit. "yellow road"). The outermost ring of each chart, just inside the neat line, is the ecliptic. The stacked smaller characters are the binomial names of the Chinese twenty-four fortnightly periods. The outermost ring is also divided into twelve equal arcs of thirty degrees, each of which correspond to the twelve Chinese zodiac divisions of the ecliptic. The two larger characters in each arc section name one of twelve zodiacal signs by combining one of the twelve earthly branch names and the character gong (宮, "palace" or "mansion"). For example, at the top of the southern hemisphere are the large characters for the chougong (丑宮) or the second earthly-branch palace. That name corresponds to the Chinese zodiac figure of the ox, the Western sign of Taurus. The arc section to the left, counterclockwise, has the characters yingong (寅宮), the third earthly-branch palace, which corresponds to the Chinese zodiac figure of the tiger, the Western sign of Gemini, and so forth. The 1723 Huangdao zong xingtu was a physical and visual manifestation of part of the complex imperial system related to the "order" of time and space and as such can be considered an important visual arbiter between Jesuit scientific knowledge and Qing imperial rule under the new Yongzheng emperor (1722-35).

\section{Korean Envoys}

The first king and founder of the Joseon dynasty, King Taejo (r.1392-98), established the Korean Soun Kwan (Royal Observatory and Astronomy Bureau), based on the Ming court equivalent, the Qintianjian. Often, when the Qintianjian made changes, the Joseon court wanted that new information to help secure their own spatio-temporal mandate. Through envoys both official and private, the Korean court maintained contact with the Chinese court throughout the Ming and subsequent Qing dynasties. Korean envoys knew of Jesuit work in cartography, both terrestrial and celestial, and beginning in the early part of the eighteenth century, both terrestrial and celestial mapping by the Jesuits played an active role in Korean royal proceedings. ${ }^{12}$

11 Fernando Bonaventura Moggi (1684-1761) was an Italian Jesuit lay brother who had studied fine art and architecture. He built churches and also worked in the Chinese court.

12 All official envoys were recorded in the Joseon wangjo sillok (Royal Annals of Joseon). According to references in the Joseon wangyo sillok, Korean envoys, such as Yi Gwangjeong 
In 1708, the Soun Kwan, under order from King Sukchong (r.1674-1720), made copies of the 1608 printing of Matteo Ricci's (1552-1610) Kunyu wanguo quantu (Complete map of ten thousand countries of the world, Gonyeo-manguk-cheondo [Kor.], 坤輿萬國全圖) and Adam Schall von Bell's (1592-1666) 1634 star map Huangdao nanbei liangzong xingtu (黄道南北兩總星圖). Chief State Councilor Ch'oe Sŏkchŏng $\left(1645^{-1715}\right)$ supervised the 1708 reproduction of these, writing the preface in the top left margin of the 1708 Korean copy of Ricci's map. The reason for the reproduction of these two Jesuit maps in the Joseon court at the start of the eighteenth century was twofold. First, according to the official court chronicle, in May 1708 the court wanted to correct discrepancies in the official Joseon calendar. The Chongzhen emperor's (1627-44) calendar reforms in the 1630 s had caused controversy in using Jesuits to make corrections in the late Ming, but after the Manchu conquest, these were immediately incorporated into the Shunzhi emperor's (1644-61) calendar of 1645 in the Qing. Uncertain about the legitimacy of the Qing, these calendar reforms were not fully embraced by the Joseon court, and King Sukchong wanted the discrepancies in his calendar addressed and corrected. Second, from 1704, a surge of Ming loyalism within Korea emerged with the government's ideological program to establish the Joseon dynasty $(1392-1897)$ as a legitimate heir to the imperial mantle of the fallen Ming dynasty upon the sixtieth anniversary of the Ming dynasty's 1644 collapse. Ricci's and Bell's maps had their origin in Ming China and therefore reminded the Joseon court of the ideal Chinese principles of "order" of the Ming dynasty. ${ }^{13}$

Working in Beijing from the 1720s, Kögler's efforts began to bear fruit in exchanges between the Chinese court and Korean envoys from the 1740 s and continued to do so long after his death into the 1770s. Late in Kögler's life, a number of Korean court officials studied with him at Beijing and acquired books on astronomy. In 1743, An Gukbin (1699-?), an official in the Gwansanggam (Office of the Observance of Natural Phenomena, 觀象監), along with his interpreters Byeon Junghwa (1682-?) and Kim Jaehyun (?) visited and became friends with

(1552-1629), sent to the late Ming capital of Beijing meticulously recorded the maps, including copies of Ricci's 1602 and 1603 maps, they had received as well as other books. See M. Antoni J. Üçerler, "Missionaries, Mandarins and Maps: Reimagining the Known World," in China at the Center: Ricci and Verbiest Maps (San Francisco: Asian Art Museum of San Francisco, 2016), 1-15, here 3; Huang Shijian and Gong Yingyan, Limadou shijie ditu yanjiu [Studies on Matteo Ricci's World Maps] (Shanghai: Shanghai guji chubanshe, 2004), 118; Hall of Heavenly Records Records, $175^{-78}$.

13 See Lim Jongtae, "Matteo Ricci's World Maps," and Lim Jongtae, "Learning Western Astronomy from China." 
Kögler and the then-Assistant Jianzheng Antonio Pereira. ${ }^{14}$ And in 1744 liguan (calendrical official, 曆官) Kim Taeseo (1714-?) and interpreter An Myeongyeol (1697-?) visited Kögler. ${ }^{15}$ In the following year, Kim Taeseo and An Myeongyeol purchased in Beijing, and later submitted to the Joeson court, a copy of Kögler's Lixiang kaochang houbian. ${ }^{16}$

After Kögler's death in 1746, his Jesuit colleagues continued to be in contact with Korean envoys. Kögler had collaborated with Augustin von Hallerstein and the Anton Gogeisl on the earlier Yixiang kaocheng. Von Hallerstein, Gogeisl and Felix da Rocha (1713-81) printed an enlarged Yixiang kaocheng in 1757 with a preface by the Qianlong emperor (r.1735-96). Soon after this, von Hallerstein and Gogeisl met with Hong Taeyong (1731-83), the noted Korean mathematician and astronomer who visited Beijing numerous times. Hong recorded his discussions with von Hallerstein and Gogeisl in Beijing in his travel journal of $1765 .{ }^{17}$

Hong showed particular interest in the technical information related to astronomical instrumentation. Not only did he bring back publications and expertise in Jesuit astronomical instruments to present to the court, but he also built his own private observatory in the early 1760s based on Jesuit instrumentation. The Joseon king at the time, King Yeongjo (r.1724-76), known for his extensive economic reforms, had ordered repairs made to and descriptions written of workings of the astronomical instruments by the Soun Kwan. ${ }^{18}$ The collecting and presenting to the Korean court of Beijing-produced Jesuit celestial science, both technical and practical, through envoys began in the

14 See Yeongjo shillok (“Veritable records of King Yeongjo," 英祖實錄), gwon 59, year 20, month 5, day 15, in Guksa pyeonchan 43 (Seoul: Guksa pyeonchan wiwonhoe, 1970), 136. There was also an An Gukrin (1709-?) who with the same translator Byeon Junghwa went to Beijing and collected astronomical books in 1725. Both An Gukrin and An Gukbin were from the same family lineage, the Sunheung An clan, which produced many second-grade technocrats (jungin) for the Joseon government. Although it is unclear whether they were directly related, both passed the official exams and served in the government as envoys to Beijing.

15 See Yeongjo shillok, gwon 59, year 20, month 7, day 3, in Guksa pyeonchan, 43:140.

16 See Yeongjo shillok (Veritable records of King Yeongjo), gwon 62, year 21, month 7, day 13, in Guksa pyeonchan, 43:187.

17 Tamhon Yongi (“Yanjing Memoir," 湛軒燕記 also known as 乙丙燕行錄), see Yonhaengnok sonjip (“Collection of Selected Records of Travels to Yanjing," 燕行錄選集), reprint (Seoul: Seoul National University, 1960), 240-45.

18 Chingbok munhon pigo (“Comprehensive Study of [Korean] Civilization” 增文獻備考) (1732), 3: 3b, 6a, 7a-b. 
early seventeenth century and intensified a century later until the end of the eighteenth century.

\section{Korean Star Chart Screens}

The Joseon court had a complex bureaucracy, with many political factions, that included extensive rituals supported by particular court officials that at times closely followed and at times challenged the calendrical practices of the Ming and Qing courts of China. In regard to this, the royal court sponsored the production of a large number of paintings. These employed the finest materials by members of the Bureau of Painting (Dohwaseo, 圖畫署), a division of the Board of Rites, to serve the court's symbolic and ritual needs. They frequently illustrated the values related to the interpretation of Chinese classics that the throne wanted to push forward, as well as documenting court ritual, government projects, ceremonies, palace banquets, birthday celebrations, and royal processions, thus providing visual evidence of court life at the time. The large format folding screen was the preferred and primary format of such displays, becoming an essential part of the setting of official governance and political authority and displaying the "order" of space and time in the Joseon royal court. ${ }^{19}$

Such screens were different than ones used in Japan to display Ricci's maps. In Korea, single screens, typically taller and thinner than their Japanese and Chinese counterparts, were made to stand alone. In Japan, the screen format was typically made in pairs that the viewer would sit between to create an immersive space that had different functions. In Korea, screens were used both inside and outside to create backdrops for ceremonial context and became essential agents in the setting of the royal court. For example, Sun, Moon and Five Peaks (Irworodongdo 日月五峯圖) screens were always placed in the king's public office spaces behind the royal throne. These particular screens were manifestations of Joseon political cosmology portraying the balance of heaven (sun and moon) and earth (five peaks) and the king's authority over that balance. ${ }^{20}$ They could even symbolically indicate the presence of the king himself in documentary paintings.

\footnotetext{
19 Evelyn B. McCune, The Inner Art: Korean Screens (Hanguk-eui Pyeongphung) (Berkeley: Asian Humanities Press, 1983, reprint 1997).

20 Yi Song-mi, "Euigwe and the Documentation of Joseon Court Ritual Life," Archives of Asian Art 58 (2008): 113-33.
} 


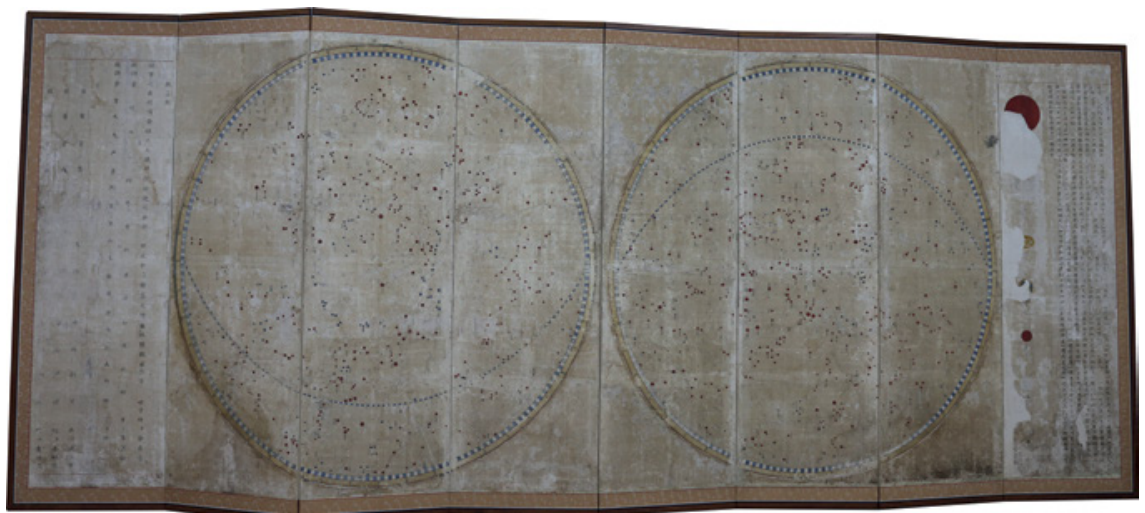

FIGURE 3.2 Sinbeop cheonmudo (Improved methods star charts, 新法天文圖), Korea, Joseon dynasty, dated Yeongjo 18 (1742), screen (eight panel), ink, gold and color on paper, $183 \times 451 \mathrm{~cm}$., Beopjusa Temple, Mount Songni in North Chong Cheong Province, South Korea, National Treasure no. 848

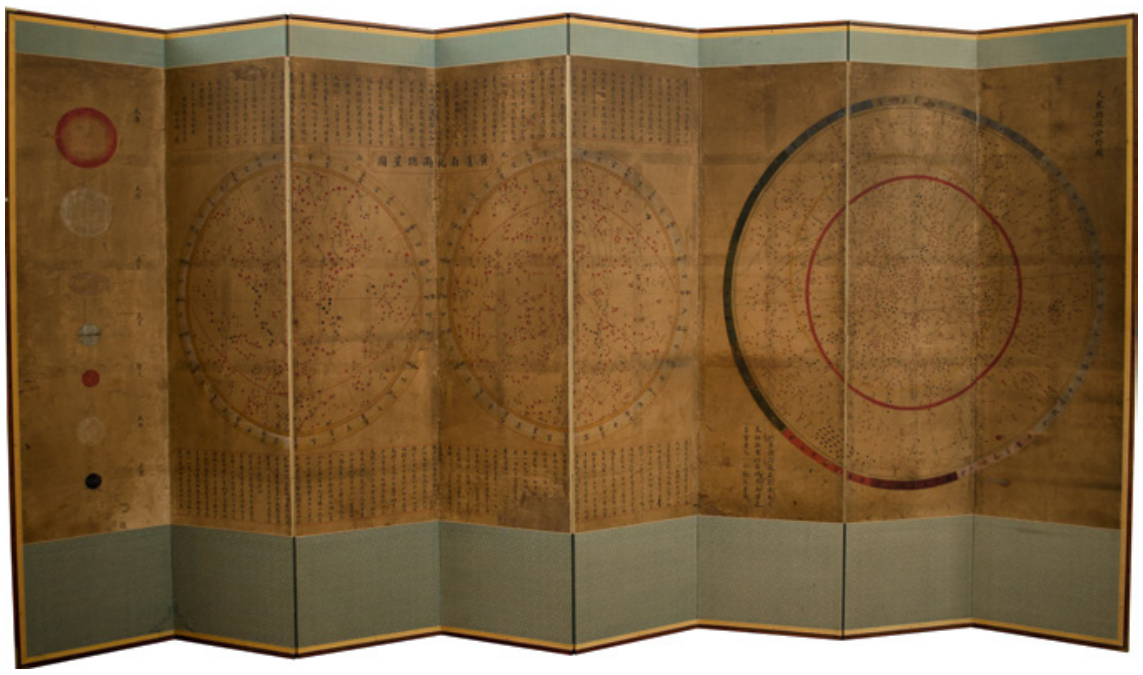

FIGURE 3.3 Sinbeop cheonmudo (Improved methods star charts, 新法天文圖), Korean, Joseon dynasty, $c .1757$, screen (eight panel), ink, gold and color on paper. The Whipple Museum of the History of Science, University of Cambridge, England

In the middle of the eighteenth century, a number of large format folding screens, four of which survive, were produced based on Kögler's 1723 Huangdao zong xingtu. These include the eight-panel screen entitled Sinbeop cheonmudo (“Improved Methods Star Charts," 新法天文圖) completed in 1742 
(Figure 3.2), ${ }^{21}$ the Sinjibeop cheonmudo (Old and improved methods star charts, 新舊法天文圖), an eight-panel screen dated circa $1750,{ }^{22}$ and the Sinbeop cheonmudo (Improved methods star chart, 新法天文圖), an eight-panel screen dated circa 1757 (Figure 3.3). ${ }^{23}$ Only during the 1740 os and 5os did the Korean court produced these screens, and in all of East Asia, only in Korea were single stand-alone screens of these star charts made. The timing is significant, coinciding with other single, albeit terrestrial, map screens produced in the court of King Yeongjo like the Seobuk piayanggye mallillam jido (Map of the northern and western frontiers of Korea, 西北彼我两界萬里一覽之圖). ${ }^{24}$ This map screen served first as a military map depicting the border between Joseon Korea and Qing China, and second as an agent of terrestrial authority depicting places associated with Joseon royal ancestor worship and the foundation myth that King Yeongjo was so keen on confirming.

The production of the Beopjusa Temple screen has been attributed to the two envoys sent to Beijing, who became friends with Kögler, namely An Gukbin, the official from the Gwansanggam and Kim Taeseo, the liguan. ${ }^{25}$ The first panel (right side) of the screen has the same lengthy introductory text (510 characters) and diagrams of the Seven Directors found on Kögler's 1723 Huangdao zong xingtu. The middle six panels of the screen show two large scale star charts along the ecliptic poles for the northern (right) and southern (left) hemispheres as found in Kögler's 1723 star charts. These include all the several thousand stars and several hundred constellations all drawn in ink only. The eighth and final panel have the names and titles of court officials, including An Gukbin, who participated in the making of the screen presenting a permanent public record of just some of the people involved in the network that created this screen. The later (by a decade) Whipple Museum and NFMK screens have longer inscriptions and Kögler's two large scale star charts, but also an additional single star chart on the far right three panels. This star chart is a copy of the one engraved on a stone stele in 1395 as ordered by King Taejo. ${ }^{26}$

21 Beopjusa Temple on Mount Songni in North Chungcheong Province, South Korea, National Treasure no. 848 .

22 National Folk Museum of Korea (NFMK), Seoul, South Korea, National Treasure no. 1318.

23 Whipple Museum of the History of Science, University of Cambridge, England. There is another star chart screen in the Nanban Bunkakan in Osaka, Japan. See Nha, Il-seong and Lee, Yong-sam, "The Eight-Fold Screen Star Map."

24 See Richard A. Pegg, Cartographic Traditions in East Asian Maps (Honolulu: University of Hawaii Press and Maclean Collection, 2014), 63-68, fig. 20.

25 See Lee, "On a New Star Map Preserved in the B bju-sa Temple," 1-66.

26 The badly damaged stele and a new copy ordered during the reign of King Sukchong were moved to the Changdok Palace in Seoul by King Yeongjo in 1770. For history of 1395 stele see Needham, Hall of Heavenly Records, ${ }_{156-59}$. 
The 1395 stele showed the classical Chinese constellations and summarized in an inscription the basic principles of Chinese astronomy at the time. King Taejo had the stele engraved as part of his legitimacy program. As the founding king of a new dynasty, Taejo was responsible for acting as intermediary between heaven and earth. By engraving a copy of the stele, he demonstrated his inherited power over all of the stars in the heavens. The stele thus represented an important visual symbol of his legitimacy. Similarly, the juxtaposition here of the 1395 star chart and the Kögler star chart on a single screen visually confirmed King Yeongjo's updated and legitimate authority as king.

On these two screens, the 1395 chart has the title Cheonsang yolja punyado (Positions of the heavenly bodies in their natural order and their allocated fields, 天象列次分野圖) on the first panel to the right. The long inscription to the lower left of the chart describes the revisions from earlier star charts made in the number of known stars. The short adjacent inscription confirms this star chart as that found on the 1395 stele. ${ }^{27}$ Constellations are connected by thin lines and colored either red, blue, or yellow according to traditional attributions. The traditional Chinese projection employed is equatorial-polar, that of terrestrial longitude and latitude. Thus the equator is shown as a complete red circle within the planisphere, while the ecliptic is a complete yellow circle intersecting it, also within the planisphere. The exterior band is divided into twelve gong (palaces) labeled in three interesting and unusual ways, including the Greek zodiac name, the earthly branch name, and the name of the ancient Chinese state that was "governed" by that group of stars. ${ }^{28}$ By comparison, the top left quadrant has the jiu and yin palaces previously mentioned in regard to Kögler's star chart. It reads in a clockwise direction: "The Palace of Gemini, [the cyclical sign] yin, the allocation [corresponding to the State of] Yan" and "The Palace of Taurus, [the cyclical sign] jiu, the allocation [corresponding to the State of] Wu."

The title for the other planispheres, panels $4^{-7}$, employs the title first utilized on Schall von Bell's star chart of 1634 and again used by Kögler in 1723 . These charts use the same three colors for the stars and maintain the Chinese constellation configurations as found on the 1395 chart. The inscription above the title and two star charts is copied from the 1723 Kögler charts with only slight variation.

Scientifically, the major difference between the charts on these screens is that the 1395 chart is equatorial-polar, using terrestrial longitude and latitude,

27 Translation in Needham, Hall of Heavenly Records, 156.

28 This band is graduated to 365.25 degrees, in the Chinese tradition. The European practice was to use 360 degrees as seen in the Kögler chart as well as the other two charts on these screens. 
while the Kögler charts are ecliptic-polar, using celestial longitude and latitude. The Kögler chart is also divided in half, making for a northern and southern chart, according to the ecliptic not the equator. The equator is still the red line but it is not an unbroken ring in the center of the chart, it appears here between the two charts like a sine wave. The ecliptic is also still yellow but is now the point of reference as the peripheral band of each Kögler chart. The lower inscription gives a historical background of classical Chinese star charts, including changes made by Ferdinand Verbiest (1623-88) and Kögler. ${ }^{29}$ The final section discusses using a telescope to find additional stars and how the telescope is used to see corrections to old star charts. The end of the inscription indirectly dates the screen to $1755^{-60}{ }^{30}$ Finally, diagrams of the Seven Directors (from top to bottom), the sun, moon, Saturn, Jupiter, Mars, Venus and Mercury, are found on the last panel, indicating the ways that traditional Korean and Chinese astronomy proved compatible with the pre-Copernican conceptions put forward by the Jesuits, who only adopted heliocentrism in 1758 when $D e$ revolutionibus was removed from the index.

All three of these screens are beautiful and impressive in their scale as they were created for and intended to be placed in the royal court as agents of royal authority over the "order" of time and space, settling debates that had become particularly acute among court factions in the aftermath of the collapse of the Ming. Visually juxtaposing an old and outdated star chart against a new and improved map on a single, large-format screen for public display, confirmed the diligence of the Soun Kwan and the court in maintaining the king's authority. ${ }^{31}$ For King Yeongjo, these screens were important visual agents of the heavens and would be put on public display during royal ceremonies confirming the "order" of the realm and confirming his rule as king.

These Korean star chart screens provide points of entry into understanding the dynamics of developing Korean science in eighteenth-century East Asia. Jesuit science had been brought to China through a vast global network of interpreters and go-betweens. This knowledge was absorbed at Beijing, becoming part of a diplomatic and tributary communication network that enabled

29 Translation in Needham, Hall of Heavenly Records, 166-68.

$30 \quad$ Needham, Hall of Heavenly Records, 168.

31 The juxtaposition of "then" a former/old visual presentation of celestial and terrestrial worlds and "now" new Western based presentations is a recurring phenomenon in late eighteenth century East Asia. The binomial term in Chinese gujin (古今) is often used in titles to represent the unique perspective on time and space found in China. For a late eighteenth century Chinese terrestrial map with gujin in the title, see Richard Pegg, "World Views: Late $18^{\text {th }}$-Century Approaches to Mapmaking in China and Britain," Orientations 44, no. 3 (April 2013): 84-89. 
its spread into Korea. Through the diplomatic network, the Korean court was kept informed about Jesuit celestial science along with technical advances in scientific instrumentation through the contact provided by envoys sent to the Ming and subsequent Qing courts. Jesuit science also allowed for a courtcentered Korean science to distinguish itself from the legacies of the Ming and perhaps even from Japan and the Qing itself. Abstract astronomical doctrines were made manifest in physical screens that became active agents in the authority of the state and its "order" of time and space. Despite the prohibition on Jesuits entering Korea, beginning in the early part of the eighteenth century and over the course of that century, Jesuit science played an active role in Korean royal proceedings; both in terms of courtly representational strategies within Korea as well as relations with Qing China. 